\title{
Thinking actively in social contexts for improving the creating thinking skills
}

\author{
Rovi Susanto *, I Gusti Putu Suryadarma \\ Universitas Negeri Yogyakarta. Jalan Colombo No 1, Karangmalang, Yogyakarta, 55281, Indonesia \\ * Corresponding Author. E-mail: E-mail: rovi45@gmail.com
}

Received: 6 September 2018; Revised: 10 December 2019; Accepted: 20 December 2019

\begin{abstract}
The study aims at developing the Thinking Actively in Social Contexts (TASC) and the fit manual book for improving the students' creative thinking skills. Within the conduct of the study, the 4D (Define, Design, Develop and Disseminate) had been adopted. First, the Define stage consisted of curriculum analysis, students' characteristics analysis, students' activities analysis and learning objectives and materials analysis. Second, the Design stage consisted of media selection, manual book format design and preliminary product prototype manufacture. Third, the Develop stage consisted of manual book prototype development with expert judgment and development test (limited experiment and expanded experiment). Fourth, the Disseminate stage consisted of manual book distribution after the manual book had been revised by the given party. Then, the results of the study show that both the TASC learning model and the manual book have been fit for improving the students' creative thinking skills. Based on the post-test results that have been analysed using the gain-score test and the t-test, it might be concluded that the students' creative thinking skills have fallen into the "High" category. In other words, the TASC learning model provides learning opportunity for the students based on the social context of the farming problems.
\end{abstract}

Keywords: TASC learning model, creative, ecosystem

How to Cite: Susanto, R., \& Suryadarma, I. (2019). Thinking actively in social contexts for improving the creating thinking skills. Psychology, Evaluation, and Technology in Educational Research, 2(1), 51-62. doi:http://dx.doi.org/10.33292/petier.v2i1.14

\section{INTRODUCTION}

The results of the needs analysis toward the students from several senior high schools in the Province of Yogyakarta Special Region show that the students' creative thinking skills have been $73.23 \%$, whereas the creative thinking skills of the $1^{\text {st }}$ State Senior High School Sanden has been $76.69 \%$. These findings imply that there should be improvemet on the creative thinking skills of the students, especially with regards to the learning process of Biology.

In relation to the above findings, the data from the Program of International Student Assessment (PISA) show that on the aspects of science Indonesia has occupied the $38^{\text {th }}$ rank consecutively from 2000 until 2003 with the score 393 and 395 (OECD, 2003; Pratama \& Istiyono, 2015; Puspitasari, 2015). Then, in 2006 Indonesia has occupied the $50^{\text {th }}$ rank with the score 393 . The program PISA itself runs the assessment toward the analytical thinking skills and the problem-solving skills. Both skills belong to the Higher Order Thinking Skills (HOTS). Departing from the statement, most of the test items (including the ones in the National Examination) in Indonesia belong to the Low Order Thinking Skills (LOTS) namely memorization, understanding and implementation ('Iffa, Fakhruddin, \& Yennita, 2017). Thus, it is apparent that the Higher Order thinking skills of the students should be improved. The improvement itself has been suggested by the results of several studies, which show that the Higher Order Thinking Skills of the Grade XI students from the Senior High School degree has not been satisfying namely $49.00 \%$ or still under the average level (Istiyono, 2014).

Problem is the the fundamental part of the creative process. Basically, each individual creates problems to be solved. Therefore, creating itself is equal to problem solving activities (Monahan, 2002, 
p. 49). Then, with regards to the statement, the creative thinking skills consisted of three aspects namely: (1) gathering ideas from all places; (2) finding new ideas; and (3) collaborating, reassuring, analysing and evaluating the ideas that have been gathered in order to be developed into the maximum output (Piirto, 2011). Furthermore, the creative skills refer to the thinking skills that cover: (1) generating (the ability to generate something); (2) planning (the ability to plan something); and (3) producing (the ability to produce/execute plans) (Anderson et al., 2001, p. 84; Anjani, 2017).

In relation to the above elaboration, the ecosystem of the $1^{\text {st }}$ State Senior High School Sanden that has been located nearby the settlement of the students might be benefitted as the learning source for the ecosystem learning and one of the most peculiar ecosystems is rice field. Based on the results of the observation toward the rice field areas in Sanden, these areas contain numerous flora and fauna such as birds, fish, molluscs and insects. In the same time, the rice fields also have highly variative cultivated plants; in the same single rice field area, the cultivated plants have been switched. Not to mention, the people in Sanden uphold several traditions that have been related to the farming activities such as Majemukan ${ }^{1}$, Kerigan $^{2}$ and Wiwit $^{3}$. The context within the social environment of farming area has huge potentials for the ecosystem learning; however, these potentials have not been benefitted well for the learning process itself.

The TASC (Thinking Actively in Social Contexts) learning model that is based on the social context of farming activities has the potentials to overcome the problems that have been mentioned previously. The TASC learning model might be implemented by the senior high school teachers in order to improve the higher order thinking skills. Then, the TASC itself has four important elements that root from the development of the thinking skills-based curriculum and the problem-solving-based curriculum for the high education degree (Haryandi, 2015; Kawuryan, 2008). The four elements are thinking activities, activeness, social contexts and relevant contexts. The social context is an integral part within the learning process. Currently, most of the schools in the Province of Yogyakarta Special Region have not implemented the TASC learning model; as a result, the model should be immediately implemented especially with regards to the learning process of Biology.

One of the farming areas around the 1st State Senior High School Sanden that might be worth to portray is Mondosio Village. The farmers in this village have adopted a farming method known as campursari ${ }^{4}$. The implementation of the campursari method is conducted by constructing the bedengan ${ }^{5}$ system, namely small square areas with 1.2-meter width each sprinkled with manure. The seeds of the red onion are planted in the first layer of the bedengan while the seeds of Kale and the seeds of bitter melon are planted in both ends of the bedengan. The presence of the bitter melon in the bedengan construction might prevent the virus outbreak among the plantations. Then, the seeds of chilli, the seeds of tomato and the seeds of eggplant are spread over their respective areas. After the chilli has grown, the chilli will be moved and will be planted again in the middle of four red onion plants. Afterward, the seeds of eggplant are planted on the left side of the bedengan system while the seeds of tomato are planted on the right side of the bedengan system. During the growth period of the plantation, the overall bedengan area is put into maintenance by watering the irrigation channels located in the sidelines of the bedengan systems. The grass that has grown should be cleared and, thus, might be benefitted as the cattle food.

Within the next two months, the red onion plants are ready for harvest while the Kale plants, as well as the bitter melon plants, might be harvested in every three days. After the red onion plants have been harvested, the seeds of lettuce start to be planted. Fifteen days later, the seeds of lettuce starts to be spread on the left side and the right side of the bedengan construction. In two weeks, the lettuce plants might be harvested and in the same time the eggplants, the tomato plants and the bitter melon

\footnotetext{
Majemukan, or also known as Tasyakuran, is an annual thanksgiving ceremony to the Creator after the harvest (https://batikgiriloyo.com/melestarikan-tradisi-majemukan/, last access January $30^{\text {th }}, 2020$ ).

2 Kerigan refers to the community service that involves the whole residents in an area such as hamlet or village (http://muamarrizapahlevi.blogspot.com/2015/02/budaya-tradisi-dan-adat-istiadat.html, last access January 30 ${ }^{\text {th }}, 2020$ ).

3 Wiwit is a ceremony that has been performed in order to begin the harvest period; Wiwit is usually performed prior to the harvest period of big-scale plants such as rice, corn and tobacco (http://dpad.jogjaprov.go.id/article/library/vieww/upacara-wiwit-602, last access January $\left.30^{\text {th }}, 2020\right)$.

4 Campursari is an agricultural method that combines farming, husbandry and fishery into one field (https://www.solopos.com/pertaniancampursari-maksimalkan-produksi-pertanian-134867, last access January $30^{\text {th }}, 2020$ ).

5 Bedengan refers to a kind of irrigation system that has been sprinkled by manure (https://www.solopos.com/pertanian-campursarimaksimalkan-produksi-pertanian-134867, last access January $30^{\text {th }}, 2020$ ).
} 
plants start to bear fruit. On the irrigation channels located in the sidelines of the bedengan construction, the seeds of catfish and the seeds of parrot fish might be spread. On the sixth month, the chilli plants will be seized and the area of the chilli plants will be dried and be loosed for the next fifteen days so that the area will stay fertile. Within two months after the drying process, this area might be planted with the red onion plants and the basil plants. The basil plants might decrease the amount of the pest on the red onion plants due to their odor. After having been harvested, the overall area will be cultivated for planting the rice until the end of the cultivation period. Through the implementation of the campursasi method, the plantations might be rotated due to the different harvest time from each plant. In the same time, the byproduct in the form of the cattle fist and the parrot fish might be either sold or consumed because both fish have high nutrition contents. The waste from the husbandry itself might be benefitted as the manure and, on the contrary, the grass around the plantation area might also be benefitted as the food for the cattle like goat and cow. Another advantage from the implementation of the campursari method is that aeration or air circulation under the ground might be constructed since the construction of the bedengan involves the activities of land enumeration prior to the planting season. The aeration itself enables numerous microorganisms to live due to the oxygen supply. In the same time, there is also a mutual relationship between one plant and another within the implementation of the campursari method. The mutual relationship might be found, for example, in the relationship between the kenikir ${ }^{6}$ plants that have been planted at the end of the bedengan construction and the plants that have been planted in the inside of the bedengan construction such as the bitter melon plants and the chilli plants. The flowers of the kenikir plants have striking colors that might grasp the attention of the insects, especially bees, so that the insects will get closer to the bedengan construction. The presence of the bees is very helpful for the pollination process of the flowers; consequently, the amount of both the bitter melon fruit and the chilli fruit might increase.

The TASC learning model has not been developed maximally in Indonesia. Most of the studies only implement TASC in the learning process of Social Science or Language. Actually, through a further study, it might be confirmed that the TASC learning model is very good to be implemented in the learning process of Natural Science or Biology within the senior high school degree. The reason is that TASC has been founded on the theory of constructivism by Vigotsky, which states that students are able to construct their own knowledge through inter-individual or social process.

A good learning process is the one that has direct relationship to the project under study. With regards to the statement, the learning process of Ecosystem is mostly based on textbooks whereas these textbooks might have certain limitations. Based on the results of the interview with the teachers, it is found that the students are rarely invited to go outside their classroom in order to have direct interaction with the objects that they study due to the limited environment. For example, in terms of location, learning period, cost and sometimes phenomena, the students do not have complete and meaningful lesson that might be grasped briefly. Therefore, there should be breakthroughs in order to bring all of the information from outside into the classroom. One of the efforts that might be pursued for achieving this end is documenting the objects that have been found in the environment and delivering this information into the classroom or being benefitted as the accompanying materials while planning the outdoor activities.

There are several alternatives of ecosystem around the students' settlement that might be benefitted as the necessary learning sources for the Ecosystem learning. One of these alternatives is rice field. With regards to this alternative, the location of the $1^{\text {st }}$ State Senior High School Sanden is in the village, which is surrounded by many rice fields. The streets that lead to the state senior high school go through many rice field areas; as a result, the students might view the social activities of the farmers who have been working in the rice field. It is the social context of the farmers that will be very interesting to be discussed within the TASC-based ecosystem learning.

Departing from the overall elaboration, the study is conducted in order to identify the fitness of the TASC learning model that has been developed in improving the students' creative thinking skills, to identify the achievement of the students' creative thinking skills score on the learning materials of Ecosystem and to identify the fitness of the TASC learning model in improving the students' creative thinking skills for the learning materials of Ecosystem. Then, the product that will generated from the

\footnotetext{
${ }^{6}$ Kenikir (Cosmos caudatus) belongs to the member of aster flowers; these flowers are part of Asteraceae, which has occupied the biggest group of the flowering plants (https://www.greeners.co/flora-fauna/kenikir-tumbuhan-liar-kaya-khasiat/, last access January $30^{\text {th }}$, 2020).
} 
study is the manual book of TASC learning model development; this manual book might be considered as a breakthrough in the domain of education for Biology. The manual book itself contains: (1) guidelines on the implementation of TASC learning model in the learning process of Biology for Senior High School degree; (2) examples of lesson plans that have been developed by using the TASC learning model; (3) students' working sheet; and (4) thinking skills test (TKB, Tes Kemampuan Berpikir) that might be administered for identifying the score of the students' creative thinking skills.

\section{METHOD}

The study was a Research and Development (R\&D) initiative. The development model that had been adopted in the study was the 4-D type model that had been developed by (Thiagarajan, Semmel, \& Semmel, 1974). This model consisted of four stages namely: (1) Define; (2) Design; (3) Develop; and (4) Disseminate. Through the adoption of the method, a product was expected to be generated in the form of manual book for the implementation of TASC learning model on the learning process of Biology for the Grade X students of the $1^{\text {st }}$ State Senior High School Sanden Bantul. The study itself took place from February until March 2015.

As having been explained previously, the stages of development in the 4-D Model consisted of Define, Design, Develop and Disseminate. In the Define stage, the learning (instructional) requirements were defined and assigned. In addition, the objectives and the problems were set as the standards for the lesson plan design. The Define Stage thus consisted of the following sequence: (1) Front-End Analysis, which aimed at identifying the underlying problems in the study with regards to the content standards, the process standards, the assessment standards and the relevant learning theories and also at scrutinizing the learning problems that had been found in the field; (2) Learner Analysis, which aimed at identifying the characteristics of the students; (3) Task Analysis, which aimed at attaining the details about the assignments that the students should complete in the learning process; (4) Concept/Material Analysis, which aimed at attaining the arrangement of the learning materials that should be delivered to the students systematically; and (5) Instructional Objectives Specification, which aimed at attaining the indicators of Competence Standards/Basic Competences achievement based on the material analysis that had been previously conducted. Then, in the Design Stage the prototype of the product was designed. The Design Stage consisted of the following sequence: (1) media selection; (2) format selection; and (3) initial design. Next, in the Develop Stage, the objective was to generate well-qualified (valid, practical and effective) manual book. This stage consisted of the following sequence: (1) Expert Appraisal, which aimed at attaining the validation of the experts with regards to the validity of the learning model that had been designed; and (2) Development Test, which consisted of limited experiment and expanded experiment. Eventually, in the Disseminate Stage, the objective was to disseminate the product that had been resulted from the conduct of the study. The manual that had been designed was intended to provide benefits for the people especially among the educators and the government as the stakeholders of education.

Specific to the study, several modifications had been made in several syntaxes of TASC learning model in order to adjust the TASC learning model into the Indonesian learning atmosphere especially in relation to the Educational Unit Level Curriculum (KTSP, Kurikulum Tingkat Satuan Pendidikan), the characteristics of the senior high school students and the learning materials of ecosystem. Based on several literature reviews and the suggestions of the TASC learning model developer, Belle Wallace, the syntax of the TASC learning model in the study consisted of five learning steps. In the first step, the sequence of Gather, Organize and Identify into a single step. The objective of the combination was to uncover the preliminary problems that the students had and to identify the problems that had been related to the learning materials that the students should learn. Then, in the second step, the sequence of Decide was accompanied by the sequence of Plan. In this step, both the teachers and the students altogether planned the activities that the students should perform in order to solve the problems that had been assigned previously. Next, the third step was still the sequence of Implement. Furthermore, in the fourth step the sequence of Evaluate and the sequence of Communicate was combined. Last but not the least, the fifth step was still the sequence of Learn from Experience. The original syntax of the TASC learning model was implemented to the students from the elementary school degree and the students from the junior high school degree. Consequently, once again, it should be noted that the syntax of the TASC learning model should be adjusted to the 
Psychology, Evaluation, and Technology in Educational Research, 2 (1), 2019, 55

Rovi Susanto, I Gusti Putu Suryadarma

characters of the students from the senior high school degree. The overall sequences of the syntax development might be consulted in Table 1 .

Table 1. The Sequences of TASC Learning Model Development

\begin{tabular}{|c|c|c|c|}
\hline Original Syntax & First Revision & Second Revision & Third Revision \\
\hline $\begin{array}{l}\text { 1. Gather and } \\
\text { Organize }\end{array}$ & $\begin{array}{ll}\text { 1. } & \text { Gather and } \\
\text { Organize }\end{array}$ & 1. Gather/Organize & $\begin{array}{l}\text { 1. Gather, Organize and } \\
\text { Identify }\end{array}$ \\
\hline 2. Identify & 2. Identify & 2. Identification & 2. Decide and Plan \\
\hline 3. Generate & $\begin{array}{l}\text { 3. Generate and } \\
\text { Decide }\end{array}$ & $\begin{array}{l}\text { 3. Idea Generation and } \\
\text { Decision }\end{array}$ & 3. Implement \\
\hline 4. Decide & 4. Implement & 4. Implementation & $\begin{array}{l}\text { 4. Evaluate and } \\
\text { Communicate }\end{array}$ \\
\hline 5. Implement & 5. Evaluate & 5. Work Evaluation & 5. Learn from Experince \\
\hline 6. Evaluate & 6. Presetation & 6. Presentation & \\
\hline 7. Communicate & $\begin{array}{l}\text { 7. Reflection and } \\
\text { Conclusion }\end{array}$ & $\begin{array}{l}\text { 7. Reflection and } \\
\text { Conclusion }\end{array}$ & \\
\hline $\begin{array}{l}\text { 8. Learn from } \\
\text { Experience }\end{array}$ & & & \\
\hline
\end{tabular}

The sequence of the test in the study consisted of three phases namely: (1) expert judgment; (2) limited experiment; and (3) expanded experiment. The conduct of the expert judgment aimed at gathering the assessment from the experts toward the manual book of the Thinking Actively in Social Context (TASC) learning model and the students' creative thinking skills test; the assessment was related to whether the manual book and the test that had been designed had already been valid or not. Then, the conduct of the limited experiment aimed at viewing the readability of both the manual book of TASC learning model and the students' creative thinking skills test. The conduct of the limited experiment involved 9 students from Grade $\mathrm{X}$ who had been selected randomly as the sample. Next, the conduct of the expanded experiment, or also known as the limited experiment, aimed at identifying the quality of the product that had been developed, namely the manual book of TASC Learning Model for the Senior High School Students, in terms of validity, practicality and effectiveness. In the same time, the conduct of the expanded experiment aimed at identifying whether the product should be revised or not. The conduct of the expanded experiment occupied a wider scale and involved the students from two different classrooms who had been taught by the same teacher in the $1^{\text {st }}$ State Senior High School Sanden. In order to identify the practicality of the learning model that had been developed, at the end of the learning process both the teacher and the students were invited to assess the TASC Model by completing the teacher assessment sheet and the student assessment sheet. Afterward, the students were invited to complete the creative thinking skills test, which results were processed in order to identify the effectiveness of the learning model that had been developed.

As having been explained, the subjects in the expanded experiment were 56 students from two classrooms of Grade X namely Grade X3 (as the experimental group) and Grade X4 (as the control group). Then, in gathering the data, the techniques that had been adopted were namely: (1) documentation; (2) questionnaire; (3) test; and (4) observation. On the other hand, in gathering the data, the instruments that had been distributed were namely: (1) validation sheet; (2) practicality assessment sheet for both the teacher and the students; (3) syntax achievement observation sheet; and (4) students' creative thinking skills test. The data that had been gathered were processed and were analysed in order to meet the objective of the study, namely to generate the fit TASC learning model. The criteria of fitness within the conduct of the study were related to the fulfillment of validity, practicality and effectiveness.

The results of the data analysis that had been attained from both the experts and the practitioners were used in order to identify the validity of the product that had been generated from the aspects of theory and consistency among the components of the product that had been developed. Then, the results of the data analysis from the expanded experiment served as the basis for determining the practicality and the effectiveness of the product that had been developed. In order to accomodate these results, a conversion table should be designed. The conversion table was designed by converting the scores from the expert judgment, the teacher/practitioner and the students into the five-scale standards (Azwar, 2010, p. 163). In this regard, the benchmark that had been adapted from Azwar was implemented and this benchmark might be consulted in Table 2 . 
Psychology, Evaluation, and Technology in Educational Research, 2 (1), 2019, 56

Rovi Susanto, I Gusti Putu Suryadarma

Table 2. The Conversion from the Quantitative Data to the Qualitative Data

\begin{tabular}{|c|c|}
\hline Interval & Criteria \\
\hline$M i+1,5 S B i<\mathrm{M}$ & Very Good \\
\hline$M i+0,5 S B \mathrm{i}<\mathrm{M} \leq M i+1,5 \mathrm{Sbi}$ & Good \\
\hline$M i-0,5 S B \mathrm{i}<\mathrm{M} \leq M i+0,5 \mathrm{Sbi}$ & Moderate \\
\hline $\mathrm{Mi}-1,5 \mathrm{SBi}<\mathrm{M} \leq \mathrm{Mi}-0,5 \mathrm{Sbi}$ & Poor \\
\hline $\mathrm{M} \leq \mathrm{Mi}-1,5 \mathrm{Sbi}$ & Very Poor \\
\hline
\end{tabular}

Note:

$\mathrm{M}=$ actual score

$\mathrm{Mi}=$ half of maximum ideal score and minimum ideal score

Sbi $=$ one-sixth of the results of maximum ideal score subtracted by the minimum ideal score

The analysis technique of the data validity included each component of the product that had been developed namely the validation of the TASC Model, the lesson plan and the creative thinking skills test. The data analysis was conducted by converting the quantitative data in the form of scores from the assessment results for each component into the qualitative data.

On the other hand, the analysis of the practicality data consisted of two aspects namely the teacher assessment and the student assessment with regards to the practicality of the implementation of the TASC learning model for the Grade X students and also the results of the observation toward the achievement of the TASC model-based learning process. The practicality of the learning model within the study was viewed from the consistency of the assessment toward the two aspects.

Next, the data analysis for determining the effectiveness of the TASC learning model that had been developed was conducted by processing the data from the results of the creative thinking skills test that had been attained from both the control group and the experimental group. The product that had been developed in the form of TASC learning model was considered fit for implementation in the learning process of Biology based on the following standards: (1) at least $75 \%$ of the students who had been involved as the subjects in the study achieved the Minimum Passing Grade (KKM, Kriteria Ketuntasan Minimal) that had been assigned, namely 70; and (2) there had been improvement on the percentage of the creative skills based on the results of the pre-test and the post-test. In order to identify the improvement from the pre-test to the post-test of the students' creative thinking skills test, the t-test and the gain score calculation were conducted. Prior to the conduct of the experiment by involving the control group and the experimental group, the data that had been attained from the pretest results should be analysed first in order to identify whether the students from the control group and the students from the experimental group had equal skills prior to the provision of the treatment or not.

The balance test was conducted when the two groups had not been exposed to the treatment. The objective of conducting the balance test was to identify whether the two groups had equal skills or not. Then, prior to the conduct of the t-test, a prerequisite test, namely the Kolmogorov-Smirnov test, was conducted by means of SPSS. The conduct of the Kolmogorov-Smirnov test consisted of three parts namely normality test, Levene's test and homogeneity test. All of the three tests were performed by running the SPSS software. The types of variables and the data gathering instruments might be consulted further in Table 3.

Table 3. The Types of Variables and the Data Gathering Instruments

\begin{tabular}{|c|c|c|c|c|}
\hline No. & Variable & $\begin{array}{c}\text { Criteria of } \\
\text { Product Quality }\end{array}$ & Type of Instrument & $\begin{array}{l}\text { Type of } \\
\text { Data }\end{array}$ \\
\hline \multirow[t]{2}{*}{1.} & $\begin{array}{l}\text { TASC } \\
\text { Learning } \\
\text { Model }\end{array}$ & Validity & $\begin{array}{l}\text { Manual Book of the Learning Model, Validation Sheet, } \\
\text { Lesson Plan Validation Sheet, HOTS Test Validation } \\
\text { Sheet }\end{array}$ & Qualitative \\
\hline & & Practicality & $\begin{array}{l}\text { Practicality Assessment Sheet for the Teacher, } \\
\text { Practicality Assessment Sheet for the Students, } \\
\text { Observation Sheet for the Achievement of TASC } \\
\text { Learning Model Syntaxes }\end{array}$ & Qualitative \\
\hline 2. & $\begin{array}{l}\text { Creative } \\
\text { Thinking } \\
\text { Skills }\end{array}$ & Effectiveness & Creative Thinking Skills Test & Quantitative \\
\hline
\end{tabular}




\section{RESULTS AND DISCUSSIONS}

The product that has been developed is a draft of TASC learning model manual book for the learning process of Biology in the Senior High School degree. The manual book is equipped with lesson plan, student worksheet, learning video and creative thinking skills test.

The lesson plan that has been developed refers to the learning materials of Ecosystem. The lesson plan has been developed based on the Educational Unit Level Curriculum. Then, the learning model that has been adopted is TASC. The components of the lesson plan consist of school identity, subject identity, grade/semester, compulsory learning materials, time allocation, basic competence, indicators of competence achievement, learning objectives, learning materials, learning method, learning media, learning sources, learning sequence and assessment.

The learning objectives that have been formulated are based on the basic competence by using the operational verbs that might be observed and measured and include attitude, knowledge and also skills. The formulation of the learning method, the learning media and the learning sources are adjusted to the characteristics of TASC.

Furthermore, the learning sequence that has been formulated in the lesson plan is adjusted to the TASC learning model that has been developed. The syntaxes in the TASC learning model consist of the following stage: (1) Generate, Organize and Identify; (2) Decide and Plan; (3) Implement; (4) Evaluate and Communicate; and (5) Learn from Experience.

The development of the student worksheet is performed after the feedback from the validator (the lecturers) has been retrieved. The objective of retrieving the feedback is to facilitate the students in performing the learning activities within the classroom. The composition of the student worksheet itself is adjusted to the learning steps that have been elaborated in the lesson plan. In addition, the activities that have been outlined in the student worksheet are designed in such a way that the syntaxes of the TASC learning model might be met.

Next, the development of the learning video refers to the lesson plan and the student worksheet. The materials in the video are taken from the rice field area around the $1^{\text {st }}$ State Senior High School Sanden. The stages of the video take consists of: (1) taking the pictures of phenomena around the rice field area; (2) analysing and classifying the pictures; (3) composing the scenario of the storyline; and (4) editing the pictures and dubbing the video by the narrator.

Last but not the least, the creative thinking skills test aims at measuring the students' creative thinking skills level after the learning process has been conducted. The test items that have been usually administered are essay. Then, the test items have been designed in such a way that the test items might measure the students' creative thinking skills. After the draft of the test items has been completed, the draft of the test items should be consulted to the lecturers in order to be assessed whether the test items have been fit into and have met the standards of the good test items or not.

The draft of the product that has been developed should be validated by the experts and the practitioners. The validators observe the accuracy and the relevance of the materials among the lesson plan, the student worksheet and the creative thinking skills test. Prior to the validation process, the instrument should be presented before 2 lecturers and 20 colleagues of Biology Study Program, Science Education Graduate Program, Universitas Negeri Yogyakarta. The results of the validation by the experts and the practitioners will serve as the basis for improving the draft of the product (the first product revision).

The product validation is performed by means of validation sheet. The validation sheet contains several aspects of assessment for each component in the manual book of TASC learning model. The aspects of assessment consist of 4 scales that span from "Very Good" until "Very Poor." At the end of the validation sheet, a section of overall conclusions and suggestions toward the fitness of the manual book of TASC learning model is available. The experts who validate the manual book of TASC learning model are the lecturers who have the expertise in domain of Education and Environmental Science. These experts are also the lecturers from the Science Education Master Program of Universitas Negeri Yogyakarta. The validation itself consists of manual book validation, lesson plan validation, and creative thinking skills test validation.

Based on the results of the manual book assessment by the validators, the manual book of TASC learning model implementation belongs to the "Very Good" category with several notes and 
feedback for revision. Thereby, the manual book that has been developed is fit for implementation in the study after having been revised.

The readability test of the student worksheet for the learning process of Biology in the study shows that in minimum the mean score from 9 students belongs to the "Very Good" category. Thus, based on the results of the readibility test, it might be concluded that the student worksheet belongs to the "Good" category without any note and feedback for revision. Therefore, in overall it might be concluded that the manual book has already been fit for implementation.

The development of the product, namely the manual book of the TASC learning model, that has been completed is considered practical based on the results of the teacher assessment. The reason is that the mean score of the teacher assessment has already passed the minimum standard for the product that has been developed. The mean score that the teacher has assigned is 43 , which refers to the "Very Good" category for the product. In addition, the teacher states that the learning model has been good and has been fit in accordance to the learning objectives.

Table 4. The Results of the Readability Test by the Students

\begin{tabular}{ccc}
\hline Student & M-Score & Category \\
\hline 1 & 20.00 & Moderate \\
2 & 25.00 & Good \\
3 & 22.00 & Good \\
4 & 25.00 & Good \\
5 & 24.00 & Good \\
6 & 22.00 & Good \\
7 & 29.00 & Gery Good \\
8 & 26.00 & Good \\
9 & 27.00 & Good \\
\hline
\end{tabular}

Furthermore, based on the results of the student assessment, the development of the product, namely the manual book of TASC learning model, within the study is already considered practical. The reason is that approximately $75.00 \%$ students state the "Good" and the "Very Good" category, namely $96.00 \%$.

Then, the results of the data analysis toward the test items, which only consist of essay, show that the item reliability 0.84 with the "Good" category. On the other hand, the person reliability score for the post-test items that have been administered is 0.57 with "Weak" category and the Cronbach Alpha score as the test reliability score is 0.66 with the category "Moderate." These findings describe that the type of the test items has already been fit into the assesment of the creative thinking skills for the Grade X students of the $1^{\text {st }}$ State Senior High School Sanden.

The post-test results show good findings. Two students have not been able to pass the Minimum Passing Grade that has been assigned namely 70 . Based on the results of the post-test, it is found that 91.70\% students have passed the Minimum Passing Grade. The statement implies that the product that has been developed, namely the TASC learning model, has been effective for implementation in the learning process of Biology because 75.00\% of the students have passed the Minimum Passing Grade.

On the other hand, the results of the hypothesis test in the control group show that significance value of the control group has been higher than 0.05 , namely 0.826 . The implication of the statement is that there has not been any significant difference between the pre-test results and the post-test results. Thus, it might be inferred that the learning process in the control gorup does not deliver any significant change on the score of the creative thinking skills. In the meantime, the results of the t-test for the experimental group, which are shown in Appendix 1g, show that the significance value of the experimental group has been lower than 0.05 namely 0.000 . The implication of the statement is that there has been significant difference between the pre-test results and the post-test results. Therefore, it might be inferred that the learning process in the experimental group delivers significant change on the score of the creative thinking skills.

Based on the results of the gain score test in the Appendix 3c, it is found that the average gain score is 0.73 , which belongs to the "High" category $<\mathrm{g}>\geq 0.70$. Two students still have low gain score while $92.00 \%$ students have high gain score. The conclusion that might be made in this regard is that the implementation of the TASC learning model is able to improve the creative thinking skills of the 
Psychology, Evaluation, and Technology in Educational Research, 2 (1), 2019, 59

Rovi Susanto, I Gusti Putu Suryadarma

students significantly. The distribution of the students' creative thinking skills might be consulted in Table 6.

Table 5. The Results Summary from the Conduct of the Study

\begin{tabular}{|c|c|c|}
\hline No. & Aspects & Information \\
\hline 1. & $\begin{array}{l}\text { Assessment and validation of the manual book of TASC } \\
\text { learning model by the expert lecturer }\end{array}$ & Very Good + Minor Revision \\
\hline 2. & $\begin{array}{l}\text { Assessment and validation of the lesson plan by the expert } \\
\text { lecturer }\end{array}$ & Very Good + Minor Revision \\
\hline 3. & $\begin{array}{l}\text { Assessment and validation of the creative thinking skills } \\
\text { test by the expert lecturer }\end{array}$ & Very Good + Minor Revision \\
\hline 4. & Assessment on the test readability by the students & Good Without Revision \\
\hline 5. & Assessment on the test practicality by the teacher & $\begin{array}{l}\text { Good Without Revision }+ \text { Suggestions for } \\
\text { Further Development }\end{array}$ \\
\hline 6. & Assessment on learning model practicality by the students & $\begin{array}{l}\text { Good Without Revision by } 96.00 \% \\
\text { Students }\end{array}$ \\
\hline 7. & Implement of each syntax in the TASC learning model & $100.00 \%$ Implemented \\
\hline 8. & $\begin{array}{l}\text { Test item reliability for the students' creative thinking skills } \\
\text { test }\end{array}$ & "Good” Category \\
\hline 9. & Achievement of minimum passing grade & $\begin{array}{l}\text { Minimum Passing Grade Achieved by } \\
91.70 \% \text { Students }\end{array}$ \\
\hline 10. & Improvement on the creative thinking skills & $\begin{array}{l}\text { Good Achievement of Gain Score by } \\
92.00 \%\end{array}$ \\
\hline
\end{tabular}

Table 6. The Distribution of the Students' Creative Thinking Skills

\begin{tabular}{cc}
\hline Range of Score & Number of Students \\
\hline $90-100$ & 10 \\
$81-90$ & 4 \\
$71-80$ & 8 \\
$61-70$ & 1 \\
$51-60$ & 1 \\
\hline
\end{tabular}

The results of the experimental group, which has been exposed to the TASC learning model as the treatment, show high improvement on the creative thinking skills. The improvement of the students' creative thinking skills is not apart from the successful implementation of the TASC learning model. The reason is that the TASC learning model provides opportunities for the students to learn based on the social context within the scope of their environment. The social context itself is the farming activities that take place in the rice field ecosystem around their school. Through this social context, the students are exercised to understand the learning materials more easily. In the same time, the creative thinking skills of the students are trained to solve the problems that appear in the social context of the rice field.

The learning activities in the TASC learning model highly support the improvement of the students' creative thinking skills. During the learning process, the students are exposed to the facts about the rice field ecosystem. These facts show various peculiar biotic and abiotic components from the rice field ecosystem in Sanden. Numerous phenomena of interaction within the ecosystem are also well-presented so that the students might observe and understand these phenomena well. The phenomena of interaction that have been presented are also peculiar, namely the interaction in the rice field ecosystem.

The exercise of the students' creative thinking skills become the main focus in the TASC learning model that has been implemented in the school. During the learning process, the students are asked to identify the problems that exist in the ecosystem and then the students are asked to identify the appropriate solutions for overcoming the problems that have been identified. Then, the problems that have been discussed in the social context of the farming area are as follows: (1) overwhelming chemical fertilization in the rice field; (2) air contamination in the rice field; (3) waste and garbage that enter the rice field; (4) use of pesticide in the rice field; (5) monoculture farming pattern; (6) impact of each problem on the presence of the ecosystem component; and (7) ecosystem balance. The use of the problems that have been close to the daily life of the students will facilitate the students in thinking and training their skills of defining the appropriate solutions. It is this process that might 
improve the students' creative thinking skills. Then, the factors that might support the success of the TASC learning with regards to the improvement of the students' creative thinking skills are as follows: (1) all of the syntaxes in the TASC learning model might be well implemented so that the students become active in the learning process; (2) the social context of farming activities that have been proposed in the learning is interesting and relevant for the students because this context is relevant to the students' daily experience; (3) the learning activities are interesting and enjoyably designed so that the students become interested and develop their sense of curiosity; (4) the provision of the examples that have been taken from the surrounding environment is very interesting and helpful for the students in understanding the ecosystem; (5) the learning videos that have been displayed are very clear and meaningful for the students; and (6) the students have not attained any additional experience with such learning model since they have never been exposed into the learning process with the use of the TASC learning model.

The sequence of product revision still belongs to the Development stage within the Research and Development model. Product revision refers to the sequence in a Research and Development initiative that has been performed based on the data that have been attained from both the validator and the expanded or the field experiment. Then, within the Development stage, several notes and suggestions have been provided by the validator. Both the notes and the suggestions will serve as the basis for the revision. The revision itself aims at improving the product so that the product will be fit for the test. In the context of the study, the revision is directed toward the initial manual book of the TASC learning model. The revisions that should be performed are: (1) improving the layout of the manual book by expanding the paper size; (2) revising the words and the sentences that do not meet the standards of the Enhanced Spelling of Indonesian Language (EYD, Ejaan yang Disempurnakan); (3) clarifying the learning steps in the lesson plan by writing the learning sequences in the classroom complete with the activities that both the teacher and the students should perform; (4) omitting the referential sources that are not relevant in the lesson plan; (5) generating additional product in the form of simple student worksheet in order to facilitate the students within the learning process in accordance to the direction of the validator; and (6) fixing the mistypes in the students' thinking skills test instrument.

During the conduct of the limited experiment and the expanded experiment, several notes for revision have also been attained. First of all, the layout of the learning video should be improved. The improvement includes: (1) the addition of special effect at the beginning and the end of the video; (2) the addition of back-sounds; (3) the reduction of volume noise on several scenes that have been very noisy; and (4) the addition of several information on the texts of the video. In performing these revisions, a new software has been run namely Corel Video Studio Pro X5, which has been the latest issue from the Corel Uled Video Studio 11 that has been frequently run for video-editing activities previously. Then, several words and sentences that are not in accordance to the Enhanced Spelling of Indonesian Language should be improved. Last but not the least, the layout of the manual book cover should be improved so that the manual book will be more interesting.

The subsequent stage in the study is Disseminate. In this stage, the final product that has been generated might be disseminated to the relevant parties. The product that has been generated itself is the manual book of TASC learning model for the Biology learning in the Senior High School degree. The manual book of TASC learning model is equipped with the lesson plan, the student worksheet, the creative thinking skills test and the learning video.

The learning materials within the manual book of TASC learning model have been quite sufficient because the manual book contains the supporting theories of TASC learning model, the lesson plan with clear and easy-to-perform syntaxes for the students and the student worksheet that will facilitate the students in the learning activities. In addition, the manual book also contains good media in the form of a video about the rice field ecosystem with descriptions on the social context of farmers' activities in the rice field area. This video is very good because it delivers the social context around the students. Based on the statements of the students in the questionnaire that has been distributed at the end of the learning process, the video is considered valid and fit for implementation because the students are facilitated in understanding the lesson, in expanding their insight and also in developing their sense of curiosity. The evaluation in the manual book is already relevant since the evaluation instrument has been validated by the expert lecturers; the category of the evaluation instrument belongs to the "Good" category. In the same time, the reliability of the evaluation 
instrument has been tested and the item reliability of the evaluation instrument belongs to the "Good" category and the "Fit for Implementation" category as well.

The practicality of the product has been assessed by the teacher. The teacher response in the practicality questionnaire shows that the product belongs to the "Very Good" category. In addition, the teacher also expects that the learning model might be developed further for the other learning materials of Biology so that the students might be facilitated in understanding the given learning materials.

The level of effectiveness is tested by comparing the pre-test results and the post-test results of the control group and the experimental group. The first test has been conducted by using the t-test in order to identify whether there is difference or not between the pre-test results and the post-test results. The results of the t-test show that the control group does not show significant difference while the experimental group shows significant difference. Therefore, the results of the pre-test and the post-test from the experimental group should be analysed further by using the gain-score test. The results of the gain-score test show good implication. The mean score of the creative thinking skills improvement is higher than 0.70 or belongs to the "Very Good" category. On this basis, it might be concluded that the manual book of TASC learning model has been very effective in improving the creative thinking skills with the gain score 0.73 .

In brief, the scheme of the development for the manual book of TASC learning model might be consulted in Figure 1.

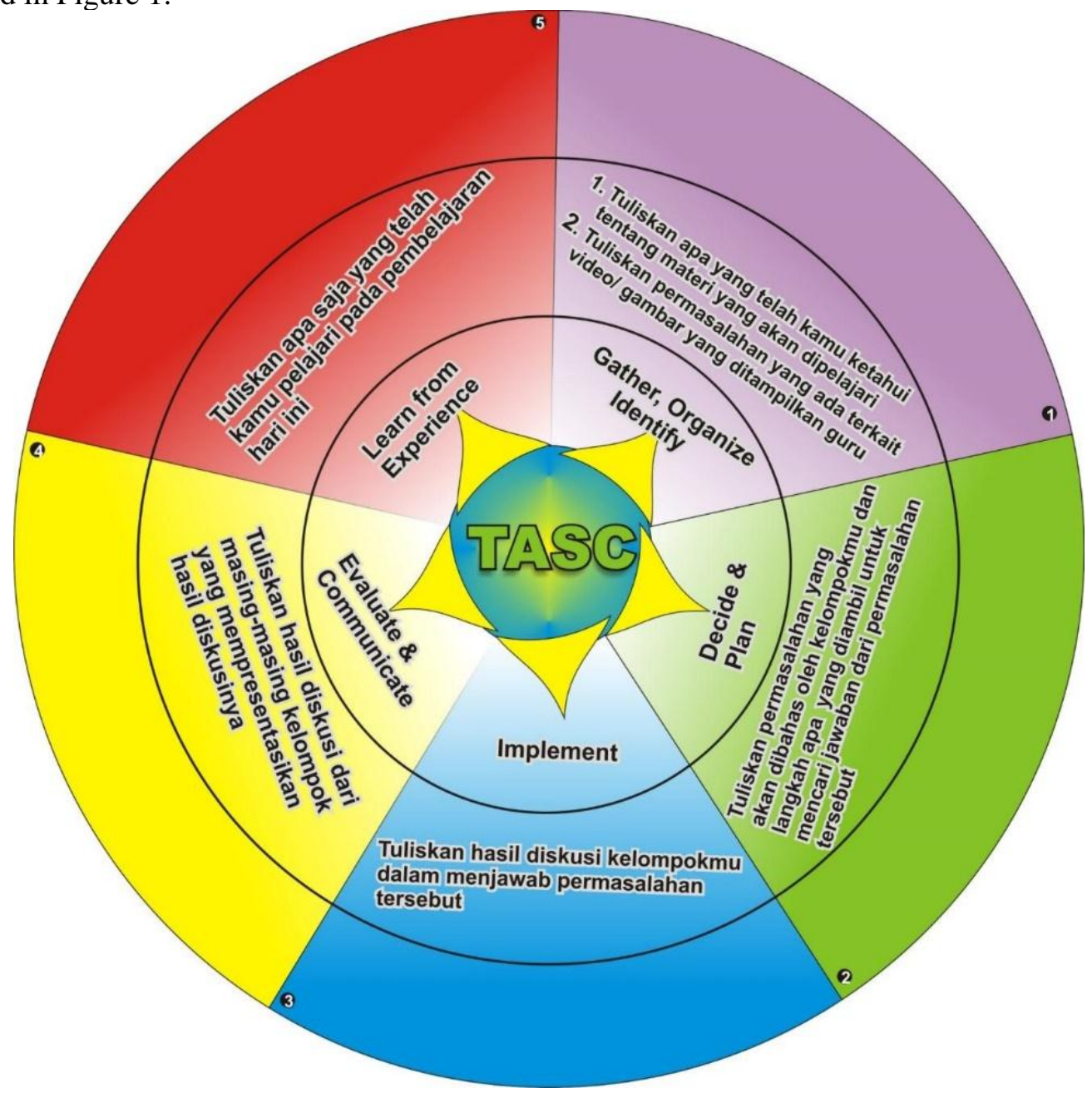

Figure 1. The Scheme of the TASC learning model that has been developed.

\section{CONCLUSIONS}

The TASC learning model that has been developed and that has been manufactured in the manual book of TASC learning model has been considered fit by the learning material expert from the aspects of content/materials, delivery, language and graphic. Then, the achievement of the students' 
creative thinking skills in Grade X of the $1^{\text {st }}$ State Senior High School Sanden has been considered "High" based on the post-test results after the learning process has been conducted by using the TASC learning model. The post-test results show that most of the students have already passed the Minimum Passing Grade and thus most of the students also display high level of the creative thinking skills. In the same time, the TASC learning model has also been considered effective based on the results of the t-test and the gain-score test. The results of both the t-test and the gain-score test imply significant difference before and after the implementation of the TASC learning model. The improvement is apparent because the TASC learning model provides opportunities for the students to learn based on the social context of the farming environment that lies in the rice field ecosystem around the school. Through this social context, it is easier for the students to understand the materials and thus to train their creative thinking skills in solving the problems that appear within the social context of the farming activities.

\section{REFERENCES}

'Iffa, U., Fakhruddin, F., \& Yennita, Y. (2017). Analisis higher order thinking skills (HOTS) siswa SMP N 1 Salo dalam menyelesaikan soal ujian nasional IPA fisika tingkat SMP/MTS. Jurnal Online Mahasiswa Fakultas Keguruan Dan Ilmu Pendidikan Universitas Riau, 4(1). Retrieved from https://jom.unri.ac.id/index.php/JOMFKIP/article/view/13525

Anderson, L. W., Krathwohl, D. R., Airasian, P. W., Cruikshank, K. A., Meyer, R. E., Pintrich, P. R., ... Wittrock, M. C. (2001). A taxonomy for learning, teaching, and assessing : a revision of Bloom's taxonomy of educational objectives. New York: Longman.

Anjani, Y. F. (2017). Analisis kemampuan berpikir tingkat tinggi menurut teori Anderson dan Krathwohl pada peserta didik kelas XI bilingual class system MAN 2 Kudus pada pokok bahasan program linier. UIN Walisongo.

Azwar, S. (2010). Tes prestasi: Fungsi dan pengembangan pengukuran prestasi belajar. Yogyakarta: Pustaka Belajar.

Haryandi, S. (2015). Pengembangan model pembelajaran TASC untuk meningkatkan kemampuan mencipta peserta didik dalam fisika. PROSIDING: Seminar Nasional Fisika Dan Pendidikan Fisika, 6(3). Surakarta: Universitas Sebelas Maret.

Istiyono, E. (2014). Pengukuran kemampuan berpikir tingkat tinggi fisika peserta didik SMA di DIY. Universitas Negeri Yogyakarta.

Kawuryan, S. P. (2008). TASC sebagai Strategi Pembelajaran Aktif di Sekolah Dasar. Yogyakarta: Universtas Negeri Yogyakarta.

Monahan, T. (2002). The do-it-yourself lobotomy: Open your mind to greater creative thinking. John Wiley \& Sons.

OECD. (2003). The PISA 2003 assesment framework-Mathematics, reading, science and problem solving knowledge and skills. Retrieved from

http://www.oecd.org/edu/school/programmeforinternationalstudentassessmentpisa/pisa2003asses smentframeworkmathematicsreadingscienceandproblemsolvingknowledgeandskillspublications2003.htm

Piirto, J. (2011). Creativity for 21 st century skills : how to embed creativity into the curriculum. SensePublishers.

Pratama, N. S., \& Istiyono, E. (2015). Studi pelaksanaan pembelajaran fisika berbasis higher order thinking (HOTS) pada kelas X di SMA Negeri Kota Yogyakarta. PROSIDING: Seminar Nasional Fisika Dan Pendidikan Fisika, 6(2). Retrieved from http://www.jurnal.fkip.uns.ac.id/index.php/prosfis1/article/view/7711

Puspitasari, A. D. (2015). Efektifitas pembelajaran berbasis guided inquiry untuk meningkatkan literasi sains siswa. Omega: Jurnal Fisika Dan Pendidikan Fisika, 1(2), 1-5. Retrieved from http://jurnalomega.org/index.php/omega/article/view/23

Thiagarajan, S., Semmel, D. S., \& Semmel, M. I. (1974). Instructional development for training teachers of exceptional children: A sourcebook. Blomington: may be ordered from the Council for Exceptional Children. 